\title{
Hipertansif kişilerin hipertansiyon konusundaki tutum ve davranışları
}

\author{
Attitudes and practices of hypertensive patients on hypertension \\ Ebru Ergün Arslantaş ${ }^{1}$ Nergiz Sevinç ${ }^{2}$ (D) Fevziye Çetinkaya ${ }^{3}$ \\ Osman Günay $^{3}$ Mualla Aykut ${ }^{4}$ (D) \\ ${ }^{1}$ Zonguldak Merkez Toplum Sağlığı Merkezi, Zonguldak, Türkiye \\ ${ }^{2}$ Karabük Merkez Toplum Sağıı̆ı Merkezi, Karabük, Türkiye \\ ${ }^{3}$ Erciyes Üniversitesi Tıp Fakültesi, Halk Sağlığı Anabilim Dalı, Kayseri, Türkiye \\ ${ }^{4}$ Nuh Naci Yazgan Üniversitesi, Beslenme ve Diyetetik Bölümü, Kayseri, Türkiye
}

Öz

Amaç: Hipertansiyon tüm dünyada sık görülen bir hastalıktır ve hipertansif hastalarda farkındalık oranı düşüktür. Bu nedenle hastaların sağlığını etkileyen uygun davranışları kontrol etmesi gerekmektedir. İdeal vücut ağırığı, hareketli yaşam, tuz ve doymuş yağlardan fakir diyetle beslenme, sigara ve alkol kullanmama ve stresten uzak durma önerilmektedir. Bu araştırma hipertansiyon tanısı almış erişkin kişilerin hastalıklarının kontrolü ile ilgili tutum ve davranışları ile bunları etkileyen faktörleri belirlemek amacıyla yapılmıştır.

Gereç ve Yöntem: Bu kesitsel araştırma Kayseri ili Kocasinan, Melikgazi, Talas ve Hacılar ilçelerine bağlı 4 ayrı Aile Sağlığı Merkezi'nde yürütülmüştür. Daha önce hipertansiyon tanısı almış ve aile sağlığı merkezlerine herhangi bir nedenle başvuranlardan araştırmaya katılmayı kabul eden, 18 yaş ve üzeri 525 kişi araştırma kapsamına alınmıştır. Veri toplama aracı olarak, hastaların sosyodemografik özellikleri ve hipertansiyonla ilgili tutum ve davranışları ile ilgili 37 sorudan oluşan anket formu kullanılmıştır. Verilerin analizinde Pearson Ki-Kare testi kullanılmıştır.

Bulgular: Araştırma grubunda, düzenli ilaç kullandığını belirtenlerin oranı $\% 80,8$, düzenli doktor kontrolü yaptıranların oranı \%62,9 bulunmuştur. Katılımcıların \%27,6'sı sigara, \%9,3'ü alkol kullanmaktadır, \%36,8'i tansiyonları yükseldiğinde hekime başvurduğunu, \% 63,2'si tansiyonu düşürdüğüne inandığı yiyecek ve içecek aldığını belirtmişlerdir. Araştırmaya katılanların \% 41,1'i düzenli fiziksel aktivite yapmakta olup, $\% 70,5$ 'i yemeklerinde tuz kısıtlaması yapmaktadır. BKI değerlerine göre, erkeklerin $\% 7,0$ 'si kadınların \%16,1'i obez olarak değerlendirilmiştir.

Sonuç: Araştırma grubunda, hipertansiyon farkındalığı istenilen düzeyde değildir. Hastaların hipertansiyondan korunma önlemleri hakkında tutum ve davranışlarının yetersiz olduğu belirlenmiştir. Hipertansiyon hastalarının tedaviye uyumunu sağlamak için hipertansiyon konusunda bilgilendirilmesi, düzenli doktor kontrolü ve ilaç kullanımı konusunda yönlendirilmesi, evde kan basıncı ölçümünün öğretilmesi gerekir.

Anahtar Sözcükler: Hipertansiyon kontrolü, hipertansiyon tedavisi, tutum ve davranış.

\begin{abstract} to control their illness and the factors that affect them. admitted to family health centres for any reason.

\footnotetext{
Yazışma Adresi: Ebru Ergün Arslantaş

Zonguldak Merkez Toplum Sağlığı Merkezi, Zonguldak, Türkiye

E-mail: eearslantas@erciyes.edu.tr

Makalenin Geliş Tarihi: 05.06.2018 Kabul Tarihi: 03.09.2018
}

Aim: Hypertension is a common disease all over the world and awareness is low in hypertensive patients. For this reason, it is necessary to check for appropriate behaviour that affects the health of the patients. The study was conducted to determine the attitudes and behaviours of adults with hypertension

Materials and Methods: This cross-sectional research was carried out in four family health centres in Kocasinan, Melikgazi, Talas and Hacılar districts of Kayseri. A total of 525 people 18 years of age and over were admitted to the study who had previously been diagnosed with hypertension and who was 
Results: It was determined that, $80.8 \%$ of the study group use regular medication and $62.9 \%$ have regular physician control. Of the participants, $27.6 \%$ were using cigarette and $9.3 \%$ alcohol and $36.8 \%$ stated that they apply to the physician when their blood pressure increase and $63.2 \%$ stated that they take foods and drinks which they believe decreasing blood pressure. It was established that, $41.1 \%$ of the participants have regular physical activity and $70.5 \%$ restrict salt consumption. According to the BMI, $7.0 \%$ of men and $16.1 \%$ of women were obese.

Conclusion: Hypertension awareness in the study group is not at the desired level. It has been determined that attitudes and practices of the patients are inadequate. Hypertensive patients should be encouraged to participate in regular training programs on hypertension to ensure compliance with treatment, to be directed to regular physician control.

Keywords: Hypertension control, hypertension treatment, attitude and behaviour.

\section{Giriş}

Hipertansiyon büyük çapta önlenebilir ve kontrol altına alınabilir bir hastalık olmasına karşılık, tüm dünyada önemli düzeyde morbidite ve mortaliteye yol açmaktadır. Yüksek kan basıncı koroner kalp hastalığı, kalp yetmezliği, serebrovasküler hastalık, renal yetmezlik, periferik damar hastalığı, retinal damarlarda bozulma ve görme kaybına yol açabilir (1).

Dünya genelinde 2014 yılında, 18 yaş ve üzeri kişilerde yüksek kan basıncı $(\geq 140 / 90 \mathrm{mmHg})$ prevalansı \% 22,0'dir (2). Türkiye İstatistik Kurumu verilerine göre 2015 yılı ölüm nedenlerinin \%40,3'ü dolaşım sistemi hastalıkları kaynaklıdır. Bunun da $\% 9,7$ 'si hipertansiyon kaynaklıdır (3).

Türkiye'de, ulusal çapta yapılmış üç büyük çalışmaya göre, genel hipertansiyon prevalansı; Türk Erişkinlerinde Kalp Hastalıkları ve Risk Faktörleri (TEKHARF) çalışmasında \%33,7, Türk Hipertansiyon Prevalansı Çalışması 2'de (PATENT 2) $\% 30,3$ ve Metabolik Sendrom Sıklığı Araştırması (METSAR) çalışmasında \%41,7 olarak bulunmuştur (4-6).

Hipertansif hastalarda farkındalık oranının düşük olmasının yanı sıra, tanı almış olanlarda tedavi ve kontrol oranları da düşüktür. Türkiye'de 2003 yılında yapılan PATENT 1 çalışmasında, hipertansiyon farkındalık oranı \%40,0 iken, 2012'de yapılan PATENT 2 çalışmasında \%54,7 olarak belirlenmiştir (5). Dünya genelinde hipertansiyonu olan bireylerin yarısının antihipertansif tedavi almakta olduğu, antihipertansif tedavi alanların ise yaklaşık yarısının kan basıncının kontrol altına alınabildiği tahmin edilmektedir (7).

Hipertansiyonda tedavi ve kontrollerin düzenli olması hastalığın doğuracağı tehlikeli sonuç ve komplikasyonları engeller. Hipertansiyon ve onunla ilişkili kardiyovasküler hastalıkların kontrolünde ilaç dışı tedavi ya da yaşam şekli değişiklikleri hastalığın seyrinde büyük öneme sahiptir (8).

Hipertansiyonla ilişkilendirilen sağlıklı yaşam biçimi, bireyin sağlığını etkileyen uygun davranışları kontrol etmesi ve günlük aktivitelerini ona göre şekillendirmesidir (9). Bu nedenle; ideal vücut ağırlığı, hareketli yaşam, tuz ve doymuş yağlardan fakir diyetle beslenme, sigara ve alkol kullanmama ve stresten uzak durma önerilmektedir (10). Sekiz hafta süren ve belirli bir beslenme düzeninin uygulandığı "Hipertansiyonu Durdurmak Üzere Besinsel Yaklaşımlar (DASH)" çalışmasında, meyve ve sebzeden zengin, yağsız süt ürünleri içeren, yağ ve kolesterolden fakir, proteini hafif artırılmış bir diyetle, erişkinlerde kan basıncının $5,5 / 3,0 \quad \mathrm{mmHg}$ düşürüldüğü belirlenmiştir (11).

Tuz tüketimi kan basıncını yükselten temel faktörlerden biridir ve günlük $5-6 \mathrm{gr}$ (2.4 gr sodyum) tüketilmesi önerilmektedir. Ancak ülkemiz dahil birçok ülkede ortalama günlük tuz kullanımının 9-12 gr olduğu belirtilmiştir. Ayrıca işlenmiş ve paket ürünlerin içeriğindeki tuz oranı yüksek olduğundan bu tarz gıdaların tüketiminden kaçınılmalıdır (12). Sigara ve alkol tüketimi de kan basıncını artırmaktadır. Bu nedenle hipertansiyon hastalarında günlük alkol alımının üst sınırı erkeklerde en fazla iki içki (20-30 gram etanol), kadınlarda ise en fazla bir içki (10-20 gram etanol) olarak belirtilmiştir. Sigara ise sempatik sinir sistemini aktive ederek kan basıncında artışa ve taşikardiye sebep olmaktadır (12).

Fiziksel aktivite ve düzenli egzersiz ile de kardiyovasküler hastalık görülme riski önemli oranda azalmaktadır. Bu nedenle hipertansif hastalar haftada en az beş gün, günde en az 30 dakika boyunca tempolu yürüyüş, hafif tempolu 
koşu, yüzme ve bisiklet binme gibi aerobik egzersiz yapmaları konusunda yönlendirilmelidir $(10,12)$.

$\mathrm{Bu}$ çalışmanın amacı; hipertansiyon tanısı almış erişkin kişilerin hastalıkları ile ilgili düşüncelerini ve hastalığın kontrolü konusundaki tutum ve davranışlarını belirlemektir.

\section{Gereç ve Yöntem}

Kesitsel nitelikteki bu çalışma 2015 yılı KasımAralık aylarında Kayseri ili Kocasinan, Melikgazi, Talas ve Hacılar merkez ilçelerine bağlı dört ayrı Aile Sağlığı Merkezinde yürütüldü. Aile hekimliği birimleri küme olarak kabul edilerek toplam aile hekimlerinden 30 aile hekimliği birimi belirlendi. Araştırma için Erciyes Üniversitesi Klinik Araştırmalar Etik Kurulundan etik onay alındı (17.09.2015/423).

Türk Hipertansiyon ve Böbrek Hastalıkları Derneği'nin 2012'de yaptığı Türk Hipertansiyon Prevalans Çalışması 2'ye (PATENT 2) göre, hipertansiyon tanısı alan hastaların \%66,3'ünün yemeklerinde tuz kullanımını azalttıkları saptanmıştır (5). Bu bilgiler ışığında, araştırma bölgesinde hipertansiyon tanısı aldıktan sonra tuz kullanımını kısıtlama oranının $\% 60$ dolayında olduğu kabul edilerek örneklem büyüklüğü hesaplandı. Örneklem büyüklüğü hesabında; alfa 0,05 , güç 0,80 ve tolerans değeri 0,06 alınarak, minimum örneklem büyüklüğü 513 bulundu. Araştırmaya daha önce hipertansiyon tanısı almış ve aile sağlığı merkezlerine herhangi bir nedenle başvuranlardan araştırmaya katılmayı kabul eden 18 yaş ve üzeri 525 kişinin alınmasına karar verildi.

Veri toplama aracı olarak, araştırmacılar tarafından hazırlanan ve 37 sorudan oluşan anket formu kullanılmıştır. Anket formu iki bölümden oluşmakta olup, birinci bölümde, katılımcıların sosyodemografik özellikleriyle ilgili sekiz soru, ikinci bölümde ise hipertansiyona ilişkin tutum ve davranışları ile ilgili 29 soru bulunmaktadır. Hipertansiyon nedeniyle takip süreleri, antihipertansif ilaç kullanma durumları, düzenli ilaç kullanımı ve doktor kontrolü durumları, hastalıklarını ciddiye alma durumları ve yaşam şekilleriyle ilişkili faktörler sorgulanmıştır. Anketler, kırsal hekimlik stajı yapan Tıp Fakültesi son sınıf öğrencileri tarafından, yüz yüze görüşme yöntemiyle uygulanmıştır.

Katılımcıların boy ve ağırlık değerleri kendilerine sorularak belirlenmiş ve beden kütle indeksi (BKI) hesaplanmıştır. BKI değerlendirmesinde TEMD (Türkiye Endokrinoloji ve Metabolizma Derneği) kılavuzu esas alınarak; 18,5 'in altı 'zayıf', 18,524,99 arası 'normal', 25-29,99 arası 'fazla kilolu', 30 ve üzeri ise 'obez' olarak değerlendirilmiştir (13).

Araştırmaya katılan kişilerin ekonomik durumları kendi ifadelerine göre değerlendirilmiştir. Araştırma grubunun bazı beslenme alışkanlıkları değerlendirilirken, belirtilen besinleri 'haftada birden az tüketme' doğru uygulama olarak kabul edilmiştir.

Verilerin işlenmesi ve değerlendirilmesi SPSS 22,0 kullanılarak bilgisayar yardımıyla yapılmıştır. Tanımlayıcı analizler için veriler frekans ve yüzdelik olarak ifade edilmiştir. Verilerin analizinde Pearson Ki-Kare Testi kullanılmış, $p<0,05$ değeri bütün testler için anlamlı kabul edilmiştir.

\section{Bulgular}

Tablo-1'de görüldüğü gibi, araştırma grubunun \%45'ini erkekler, \%55'ini kadınlar oluşturmaktadır. Araştırma grubunun çoğunluğu 40-64 yaş grubundadır. Tüm hastaların yaş ortalaması $56,2 \pm 11,5$ yıl olup, bu değer erkeklerde $57,3 \pm 11,8$, kadınlarda $55,4 \pm 11,1$ yıldır. Yaş ortalamaları açısından erkek ve kadınlar arasında anlamlı fark bulunmamıştır $(p=0,065)$.

Araştırma grubunun \%59,2'si hipertansiyon dışında başka bir kronik hastalığı daha olduğunu ifade etmiştir. Katılımcıların \%40,3'ü kendisinde diabetes mellitus, \%23,5'i kalp hastalığı, \%11,0'i Astım$\mathrm{KOAH}, \% 6,1^{\prime \prime} \mathrm{i}$ romatizmal hastalık ve $\% 4,5$ 'i hiperkolesterolemi olduğunu belirtmişlerdir.

Hastaların BKI değerleri incelendiğinde, erkeklerin $\% 14,0$ 'ü kadınların \%32,5'i obez; erkeklerin $\% 61,6$ 'sı kadınların ise \%32,3'ü fazla kilolu olarak saptanmıştır. BKi açısından erkek ve kadınlar arasındaki fark istatistiksel olarak anlamlı bulunmuştur $(p=0,000)$.

Tablo-3'te görüldüğü gibi, araştırmaya katılan kişilerin \%86,0'sı hipertansiyonu ciddi bir hastalık olarak gördüklerini belirtmişlerdir. Yaş, öğrenim düzeyi ve hipertansiyon süresine göre hipertansiyonu önemli bir hastalık olarak görme durumu açısından anlamlı fark bulunmamıştır $(p>0,05)$.

Tablo-4'te görüldüğü gibi, antihipertansif ilaç kullanan, düzenli ilaç kullanımı ve doktor 
kontrolüne giden katıımcıların hipertansiyonu ciddi bir hastalık olarak görme oranları daha yüksek bulunmuştur $(p<0,05)$. Bununla beraber tuzlu gıda tüketimi az olan kişilerin de hastalığı ciddiye aldıkları tespit edilmiştir $(p=0,034)$. Ancak hem yağda kızartımış hem de hızı atıştırmalıkları tüketen katılımcılar arasında hipertansiyonu önemli bir hastalık olarak görme durumu açısından anlamlı fark bulunmamıştır $(p>0,05)$.
Tablo-5'te görüldüğü gibi, hipertansiyonlu kişilerde düzenli ilaç kullandığını belirtenlerin oranı $\% 90,7$ 'dir ve cinsiyetler arasında istatistiksel olarak anlamlı fark bulunmamıştır $(p=0,370)$.

Düzenli doktor kontrolü yaptırdığını belirtenlerin oranı \%62,9 olup, bu oran erkeklerde \%69,5, kadınlarda $\% 57,4$ bulunmuştur $(p=0,004)$. Benzer şekilde, düzenli fiziksel aktivite (tempolu yürüyüş, koşma, fiziksel egzersiz) yapanların oranı da erkeklerde daha yüksek bulunmuştur $(p=0,008)$.

Tablo-1. Araştırma grubunun sosyodemografik özellikleri.

\begin{tabular}{llrr}
\hline Özellikler & Gruplar & Sayı & $\%$ \\
\hline \multirow{2}{*}{ Cinsiyet } & Erkek & 236 & 45,0 \\
& Kadın & 289 & 55,0 \\
\multirow{3}{*}{ Yaş Grupları } & 40 yaş altı & 35 & 6,7 \\
& $40-64$ & 364 & 69,3 \\
& 65 ve üzeri & 126 & 24,0 \\
Öğrenim Düzeyi & İlkokul mezunu & 293 & 55,8 \\
& Ortaokul-Lise mezunu & 159 & 30,3 \\
Çalışma Durumu & Unniversite mezunu & 73 & 13,9 \\
& Çalışmıyor & 323 & 61,5 \\
\multirow{3}{*}{ Ekonomik Durum } & Çalışıyor & 202 & 38,5 \\
& İyi & 109 & 20,8 \\
Toplam & Orta & 368 & 70,1 \\
& Kötü & 48 & 9,1 \\
& & 525 & 100,0 \\
\hline
\end{tabular}

Tablo-2. Araştırma grubunun sağlık durumu ile ilgili bazı özellikleri.

\begin{tabular}{llcc}
\hline Özellikler & Gruplar & Sayı & $\%$ \\
\hline \multirow{3}{*}{ Hipertansiyon tanısı alma süresi } & $1-4$ yıl & 184 & 35,0 \\
& $5-10$ yıl & 225 & 42,9 \\
Antihipertansif ilaç kullanma durumu & 11 yıl ve üzeri & 116 & 22,1 \\
& Kullanıyor & 480 & 91,4 \\
Başka bir kronik hastalık & Kullanmıyor & 45 & 8,6 \\
& Var & 311 & 59,2 \\
Ailede hipertansiyon & Yok & 214 & 40,8 \\
& Var & 164 & 31,2 \\
Ailede hipertansiyon nedeniyle ölen & Yok & 361 & 68,8 \\
& Var & 149 & 28,4 \\
Kendi sağlık durumunu değerlendirme & Yok & 376 & 71,6 \\
& İyi & 188 & 35,8 \\
\hline Toplam & Orta & 247 & 47,0 \\
& Kötü & 90 & 17,2 \\
\hline
\end{tabular}


Tablo-3. Araştırma grubunun bazı tanımlayıcı özelliklerine göre hipertansiyonu ciddi bir hastalık olarak görme durumları.

\begin{tabular}{|c|c|c|c|c|c|c|}
\hline \multirow[t]{2}{*}{ Özellikler } & \multirow{2}{*}{ Gruplar } & \multirow[t]{2}{*}{$\mathbf{n}$} & \multicolumn{2}{|c|}{$\begin{array}{l}\text { Hipertansiyonu Ciddi Bir } \\
\text { Hastalık Olarak Görenler }\end{array}$} & \multirow[t]{2}{*}{$x^{2}$} & \multirow[t]{2}{*}{$\mathbf{P}$} \\
\hline & & & Sayı & $\%$ & & \\
\hline \multirow{3}{*}{ Cinsiyet } & Erkek & 236 & 205 & 86,9 & \multirow{3}{*}{0,11} & \multirow{3}{*}{0,645} \\
\hline & Kadın & 289 & 247 & 85,5 & & \\
\hline & 40'ın altı & 35 & 31 & 88,6 & & \\
\hline \multirow[t]{3}{*}{ Yaş grupları } & $40-64$ & 364 & 318 & 87,4 & \multirow[t]{3}{*}{2,66} & \multirow[t]{3}{*}{0,265} \\
\hline & 65 ve üzeri & 126 & 103 & 81,7 & & \\
\hline & İlkokul & 293 & 251 & 85,7 & & \\
\hline \multirow[t]{2}{*}{ Öğrenim Düzeyi } & Ortaokul-lise & 159 & 134 & 84,3 & \multirow[t]{2}{*}{2,46} & \multirow[t]{2}{*}{0,293} \\
\hline & Üniversite & 73 & 67 & 91,8 & & \\
\hline \multirow{3}{*}{$\begin{array}{l}\text { Hipertansiyon } \\
\text { Süresi (yıl) }\end{array}$} & $1-4$ & 184 & 157 & 85,3 & \multirow{3}{*}{0,74} & \multirow{3}{*}{0,689} \\
\hline & $5-10$ & 225 & 197 & 87,6 & & \\
\hline & 11 ve üzeri & 116 & 98 & 84,5 & & \\
\hline Toplam & & 525 & 452 & 86,0 & & \\
\hline
\end{tabular}

Tablo-4. Araştırma grubunun davranış biçimlerine göre hipertansiyonu ciddi bir hastalık olarak görme durumları.

\begin{tabular}{|c|c|c|c|c|c|c|}
\hline \multirow{2}{*}{ Özellikler } & \multirow{2}{*}{ Gruplar } & \multirow{2}{*}{$\mathbf{n}$} & \multicolumn{2}{|c|}{$\begin{array}{l}\text { Hipertansiyonu Ciddi Bir } \\
\text { Hastalık Olarak Görenler }\end{array}$} & \multirow[t]{2}{*}{$x^{2}$} & \multirow[t]{2}{*}{$\mathbf{P}$} \\
\hline & & & Sayı & $\%$ & & \\
\hline \multirow{2}{*}{$\begin{array}{l}\text { Antihipertansif ilaç } \\
\text { kullanımı }\end{array}$} & Evet & 480 & 418 & 87,1 & \multirow{2}{*}{4,56} & \multirow{2}{*}{0,033} \\
\hline & Hayır & 45 & 34 & 75,6 & & \\
\hline \multirow{2}{*}{ Düzenli ilaç kullanımı } & Evet & 476 & 415 & 87,2 & \multirow{2}{*}{5,05} & \multirow{2}{*}{0,025} \\
\hline & Hayır & 49 & 37 & 75,5 & & \\
\hline \multirow{3}{*}{ Düzenli doktor kontrolü } & Evet & 330 & 295 & 89,4 & \multirow{3}{*}{8,07} & \multirow{3}{*}{0,004} \\
\hline & Hayır & 195 & 157 & 80,5 & & \\
\hline & Evet & 79 & 62 & 78,5 & & \\
\hline Fazla tuzlu gıda tüketimi & $\begin{array}{l}\text { Hayır (haftada } 1 \text { veya } \\
\text { daha az tüketen) }\end{array}$ & 446 & 390 & 87,4 & 4,50 & 0,034 \\
\hline \multirow{2}{*}{$\begin{array}{l}\text { Yağda kızartılmış gıda } \\
\text { tüketimi }\end{array}$} & Evet & 236 & 197 & 83,5 & \multirow[b]{2}{*}{2,46} & \multirow[b]{2}{*}{0,117} \\
\hline & $\begin{array}{l}\text { Hayır (haftada } 1 \text { veya } \\
\text { daha az tüketen) }\end{array}$ & 289 & 255 & 88,2 & & \\
\hline \multirow{2}{*}{$\begin{array}{l}\text { Cips, kola, hızlı } \\
\text { atıştırmalık tüketimi }\end{array}$} & Evet & 105 & 89 & 84,8 & \multirow[b]{2}{*}{0,19} & \multirow[b]{2}{*}{0,659} \\
\hline & $\begin{array}{l}\text { Hayır (haftada } 1 \text { veya } \\
\text { daha az tüketen) }\end{array}$ & 420 & 363 & 86,4 & & \\
\hline Toplam & & 525 & 452 & 86,0 & & \\
\hline
\end{tabular}

Tablo-5. Araştırma grubunda cinsiyete göre hipertansiyon kontrolü ile ilgili olumlu davranışlar.

\begin{tabular}{|c|c|c|c|c|c|c|c|c|}
\hline \multirow{2}{*}{ Davranışlar } & \multicolumn{2}{|c|}{ Erkek (n=236) } & \multicolumn{2}{|c|}{ Kadın (n=289) } & \multicolumn{2}{|c|}{ Toplam $(n=525)$} & \multirow{2}{*}{$x^{2}$} & \multirow{2}{*}{$\mathbf{p}$} \\
\hline & Sayı & $\%$ & Sayı & $\%$ & Sayı & $\%$ & & \\
\hline Düzenli ilaç kullanma & 211 & 89,4 & 265 & 91,7 & 476 & 90,7 & 0,804 & 0,370 \\
\hline Düzenli doktor kontrolü & 164 & 69,5 & 166 & 57,4 & 330 & 62,9 & 7,57 & 0,004 \\
\hline Düzenli fiziksel aktivite & 112 & 47,5 & 104 & 36,0 & 216 & 41,1 & 6,59 & 0,008 \\
\hline Sigara içmeme & 139 & 58,9 & 241 & 83,4 & 380 & 72,4 & 37,77 & $<0,001$ \\
\hline
\end{tabular}


Araştırmaya katılan hastaların \%27,6'sı sigara, $\% 9,3$ 'ü ise alkol kullanmaktadır. Erkeklerde sigara ve alkol kullanma oranı kadınlardan daha yüksek bulunmuştur $(p=0,000)$.

Araştırma grubunda, hipertansiyon takip sürelerine göre ilaç kullanma durumu değerlendirildiğinde; düzenli ilaç kullananların oranı 11 yıl ve daha uzun süredir hipertansiyonu olan kişilerde $\% 72,3$ ile en düşük oranda bulunmuştur ve gruplar arasındaki fark istatistiksel olarak anlamlıdır $(p=0,000)$.

Araştırmaya katılan hastaların \%36,8'i kan basınçları yükseldiğinde hekime başvurduğunu, $\% 63,2$ 'si ise sarımsak, limon suyu vb. besinleri tüketerek geleneksel yöntemlerle kan basıncını düşürmeye çalıştığını belirtmiştir.

Tablo-6'da görüldüğü gibi, hipertansiyonlu bireylerin hastalıklarına yönelik bazı beslenme alışkanlıklarını doğru uygulama durumu (haftada bir veya daha az) incelenmiştir. Cinsiyete göre sadece hızlı atıştırmalık besinlerin tüketimi açısından gruplar arasında fark istatistiksel olarak anlamlı bulunmuştur. Kadınların daha fazla dikkat ettikleri görülmüştür $(p=0,018)$.

Araştırma grubunda 40 yaş altı hastaların bu besinleri daha fazla tükettikleri belirlenmiştir. Yaş grupları arasında istatistiksel açıdan fark anlamlı bulunmuştur $(p<0,001)$.

Araştırma grubu eğitim durumlarına göre değerlendirildiğinde sadece hızlı atıştırmalık yiyecek tüketme oranları üniversite mezunlarında en yüksek seviyededir ve istatistiksel açıdan gruplar arasında fark anlamlı bulunmuştur ( $p<0,001)$.

Araştırma grubundaki hastaların fazla tuzlu yiyecek tüketim oranı hipertansiyon nedeniyle takip sürelerine göre değerlendirildiğinde; aradaki fark istatistiksel olarak anlamlı bulunmamıştır $(p=0,076)$. Ancak yağda kızartılmış ve hızıı atıştırmalık yiyecek tüketim oranı 11 yıl ve üzeri hipertansiyon hastalığı olanlarda en düşük seviyededir. Gruplar arasındaki fark istatistiksel olarak anlamlıdır $(p<0,05)$.

Katılımcıların hipertansiyon tanısı konulmadan önce \%18,3'ü tuzsuz veya az tuzlu yemek yediğini belirtirken, tanı konulduktan sonra $\% 70,5^{\prime} \mathrm{i}$ yemeklerinde tuz kısıtlaması yaptığını belirtmiştir. Ayrıca \%27,8'i hipertansiyon tanısı konulmadan önce yemeklerinde zeytinyağı kullandığını belirtirken, bu oran tanı konulduktan sonra $\% 37,7$ 'ye yükselmiştir. Margarin tüketim oranı tanı konulmadan önce \%3,8 iken, tanı konulduktan sonra \%1,5'e; tereyağı kullanım oranı ise \%17,7'den \%13,7'ye düşmüştür. Ayçiçek, soya, mısırözü yağı kullanımı ise tanı öncesi \%50,7 iken tanı sonrası \%47,0'ye düşmüştür.

\section{Tartışma}

Araştırmanın yürütüldüğü dört ayrı aile sağlığı merkezinde daha önce hipertansiyon tanısı almış ve aile sağlığı merkezlerine kontrol amacıyla ya da herhangi bir nedenle başvuran kişilerden araştırmaya katılmayı kabul eden 525 kişinin yaş ortalaması 56,2 $\pm 11,5$ yıldır (21-87 yıl).

Araştırmaya katılan kişiler yaş gruplarına göre değerlendirildiğinde; \%6,7'sinin 40 yaş altında, \%69,3'ünün 40-64 yaş grubunda, \%24,0'ının ise 65 yaş ve üzerinde olduğu belirlenmiştir. Grubun $\% 45$ 'ini erkekler, \%55'ini kadınlar oluşturmaktadır. Araştırma grubu içerisinde kadınların oranının daha fazla olması, Amerika Birleşik Devletleri'nde (ABD) yapılan benzer bir çalışmada da gösterildiği gibi, hipertansiyonun kadınlarda daha yüksek oranda olmasının yanı sıra, bölgedeki kadınların sağlık hizmetlerinden daha fazla yararlanıyor olmalarından kaynaklanabilir (14). Bunun dışında erkeklerin gündüz saatlerinde çalışmaları araştırmaya katılım oranlarını etkilemiş olabilir. Ayrıca yapılan bazı çalışmalarda kadınların hipertansiyon farkındalık oranlarının erkeklerden daha yüksek olduğu belirtilmiştir. Türkiye Kronik Hastalıklar ve Risk Faktörleri (TEKHARF) çalışmasına göre kadınlarda farkındalık oranı $\% 58,0$ iken erkeklerde bu oran $\% 36,0$ olarak saptanmıştır (4). Kadınların farkındalık oranlarının yüksek oluşu, bununla beraber araştırmaya katılma isteklerinin de fazla olması kadın hastaların katıım oranını yükseltmiş olabilir.

Araştırma grubunun \%59,2'si kendilerinde, hipertansiyondan başka bir hastalık veya sağlık sorunu bulunduğunu belirtmişlerdir. Katılımcıların $\% 40,3$ 'ü kendisinde diabetes mellitus, $\% 23,5^{\prime} \mathrm{i}$ kalp hastalığı, \%11,0'ı Astım-KOAH, \%6,1'i romatizmal hastalık, \%4,5'i hiperkolesterolemi olduğunu ifade etmiştir. Hipertansiyon ile birlikte diabetes mellitus, dislipidemi ve obezite görülme olasılığı yüksektir. $\mathrm{Bu}$ hastalıklardan bazıları hipertansiyonla birlikte ateroskleroz ve kalp hastalıkları oluşumunu kolaylaştırmaktadır.

Aydemir ve ark. (15) tarafından yapılan bir çalışmaya göre, hipertansiyonun komorbidite durumunda sağııkla ilişkili yaşam kalitesi üzerine olumsuz etkisi artmaktadır. Wee ve ark. (16) tarafından Singapur'da yapılan kesitsel bir çalışmada, hipertansiyonla birlikte diyabet, kalp hastalığı, iskelet-kas hastalığı gibi kronik bir hastalığa sahip olan hastaların yaşam kalitesinin bozulduğu belirtilmiştir. 
Tablo-6. Araştırma grubunun hastalıklarına yönelik bazı beslenme alışkanlıklarını doğru uygulama durumu (haftada bir veya daha az tüketen).

\begin{tabular}{|c|c|c|c|c|c|c|c|c|}
\hline \multirow[t]{2}{*}{ Özellikler } & \multirow[t]{2}{*}{ Gruplar } & \multirow[t]{2}{*}{$\mathbf{n}$} & \multicolumn{2}{|c|}{$\begin{array}{l}\text { Fazla tuzlu } \\
\text { yiyecekler }\end{array}$} & \multicolumn{2}{|c|}{$\begin{array}{l}\text { Yağda kızartılmış } \\
\text { yiyecekler }\end{array}$} & \multicolumn{2}{|c|}{$\begin{array}{l}\text { Cips, kola, hızlı } \\
\text { atıştırmalıklar }\end{array}$} \\
\hline & & & Sayı & $\%$ & Sayı & $\%$ & Sayı & $\%$ \\
\hline \multirow{2}{*}{ Cinsiyet } & Erkek & 236 & 197 & 83,5 & 122 & 51,7 & 178 & 75,4 \\
\hline & Kadın & 289 & 249 & 86,2 & 167 & 57,8 & 242 & 83,7 \\
\hline$x^{2}$ & & & \multicolumn{2}{|c|}{0,73} & \multicolumn{2}{|c|}{1,71} & \multicolumn{2}{|c|}{5,10} \\
\hline \multirow[t]{2}{*}{$P$} & & & \multicolumn{2}{|c|}{0,392} & \multicolumn{2}{|c|}{0,163} & \multicolumn{2}{|c|}{0,018} \\
\hline & 40 'ın altı & 35 & $23^{*}$ & 65,7 & $7^{*}$ & 20,0 & 12 & 34,3 \\
\hline \multirow[t]{2}{*}{ Yaş Grupları (yıl) } & $40-64$ & 364 & 316 & 86,8 & 197 & 54,1 & 296 & 81,3 \\
\hline & 65 ve üzeri & 126 & 107 & 84,9 & 85 & 67,5 & $112^{*}$ & 88,9 \\
\hline$x^{2}$ & & & \multicolumn{2}{|c|}{11,11} & \multicolumn{2}{|c|}{25,34} & \multicolumn{2}{|c|}{52,33} \\
\hline $\mathrm{P}$ & & & \multicolumn{2}{|c|}{0,004} & \multicolumn{2}{|c|}{$<0,001$} & \multicolumn{2}{|c|}{$<0,001$} \\
\hline \multirow{3}{*}{$\begin{array}{l}\text { Öğrenim } \\
\text { Düzeyi }\end{array}$} & İlkokul & 293 & 250 & 85,3 & 167 & 57,0 & 252 & 86,0 \\
\hline & Ortaokul-lise & 159 & 132 & 83,0 & 85 & 53,5 & 121 & 76,1 \\
\hline & Üniversite & 73 & 64 & 87,7 & 37 & 50,7 & $47^{*}$ & 64,4 \\
\hline$x^{2}$ & & & \multicolumn{2}{|c|}{0,91} & \multicolumn{2}{|c|}{1,17} & \multicolumn{2}{|c|}{19,24} \\
\hline$P$ & & & \multicolumn{2}{|c|}{0,632} & \multicolumn{2}{|c|}{0.556} & \multicolumn{2}{|c|}{$<0.001$} \\
\hline \multirow{3}{*}{$\begin{array}{l}\text { Hipertansiyon } \\
\text { süresi (yıl) }\end{array}$} & $1-4$ & 184 & 149 & 81,0 & $88^{*}$ & 47,8 & $130^{*}$ & 70,7 \\
\hline & $5-10$ & 225 & 200 & 88,9 & 127 & 56,4 & 186 & 82,7 \\
\hline & $11+$ & 116 & 97 & 83,6 & 74 & 63,8 & 104 & 89,7 \\
\hline$x^{2}$ & & & \multicolumn{2}{|c|}{5,16} & \multicolumn{2}{|c|}{7,64} & \multicolumn{2}{|c|}{17,81} \\
\hline $\mathrm{P}$ & & & \multicolumn{2}{|c|}{0,076} & \multicolumn{2}{|c|}{0,021} & $<0$ & \\
\hline Toplam & & 525 & 446 & 85.0 & 289 & 55,0 & 420 & 80,0 \\
\hline
\end{tabular}

*: Fark bu gruptan kaynaklanmaktadır.

Araştırma grubundaki hastaların \%86,0'ı hipertansiyonu ciddi bir hastalık olarak gördüğünü ifade etmiştir. Bu durum yaş, cinsiyet, öğrenim düzeyi ve hastalık süresine göre değerlendirildiğinde, gruplar arasında istatistiksel olarak anlamlı fark bulunmamıştır. Ayrıca antihipertansif ilaç kullanan, düzenli ilaç kullanımı ve düzenli doktor kontrolüne giden katıımcıların hastalığı ciddiye alma oranları daha yüksek bulunmuştur.

Bununla beraber hipertansiyonu önemseyen kişilerin tuzlu gıda tüketiminin daha az olduğu saptanmıştır. Ülkemizde yapılan PATENT-2 çalışmasında, hastalığa ilişkin farkındalık dokuz yıl öncesinde yapılan PATENT çalışmasına göre \%15'lik artış göstererek \%40,0'dan \%55,0'e, hipertansiyon ilacı kullanım oranı \%31,0'den $\% 47,0$ 'e yükselmiştir (5). PATENT çalışması sonuçlarına paralel olarak, bu araştırmada da hipertansiyonu önemseyen kişilerin ilaç kullanımları ve doktor kontrollerinin daha düzenli olduğu saptanmıştır. Hastalığını önemseyen kişilerin hipertansiyon hastalığını ciddiye alıp tuz tüketimi konusunda daha dikkatli oldukları görülmektedir. 
Katılımcıların \%80,8'i düzenli olarak antihipertansif ilaç kullandığını, \%62,9'u düzenli doktor kontrolüne gittiğini ifade etmiştir. PATENT 2 çalışmasında, düzenli ilaç kullanma oranı $\% 47,0$ olarak belirtilmiştir (5). Mersin ilinde 65 yaş üzerinde yürütülen bir çalışmada, önceden hipertansiyon tanısı almış hastaların \%15,1'inin takip altında olduğu saptanmıştır (17). Bizim çalışmamızda düzenli ilaç kullanma oranları yapılan diğer araştırmalara göre daha yüksek bulunmuştur. Bu farklııı, çalışmamızın sağlık kuruluşuna başvurmuş olan hastalar üzerinde yapılmasına bağlı olabilir. Ancak, yapılan araştırmalar düzenli ilaç kullanımının yeterli düzeyde olmadığını göstermektedir $(5,17)$. Hastalığın bazen belirtisiz seyredebilmesi ve hastaların eğitim düzeyinin düşük olması gibi sorunlar bu sonucun doğmasına sebep olabilir.

Hipertansiyon takip sürelerine göre değerlendirildiğinde, 10 yıldan daha uzun süreden beri hipertansiyonu olan kişilerde düzenli ilaç kullanma oranı \%72,3 ile en düşük seviyededir. Yapılan bir çalışmada, ilaç bittiğinde temin edememe, unutkanlık, çok ilaç kullanımı (polifarmasi), fizyolojik ve duyusal fonksiyonlarda azalmalar gibi nedenlerle, ileri yaşlarda düzenli ilaç kullanımının bozulduğu belirtilmiştir (18). Belirtilen nedenlere bakıldığında, etkili bir planlama ile bu problemler çözülebilir. Ankara ve Kars'ta yapılan başka araştırmalarda da özellikle ilaç alma saatlerinin unutulması nedeniyle düzensiz ilaç kullanımının ilerleyen yaşlarda daha çok görüldüğü belirtilmiştir $(19,20)$. Bu araştırmanın bulguları da literatürle uyumlu olup, tanı konduktan yıllar sonra hastaların ilaç kullanımı ile ilgili uyumlarının bozulduğunu göstermektedir.

Alkol ve sigara kullanımı, sağlıksız beslenme ve sedanter yaşam kalp hastalığı ve hipertansiyon riskini artırmaktadır (15). Katılımcıların sigara ve alkol kullanma durumları değerlendirildiğinde; erkek hastaların \%41,1'inin sigara, \%16,1'inin alkol kullandığı, kadın hastaların \%16,6'sının sigara, \%3.8'inin alkol kullandığı belirlenmiştir. Erkeklerde sigara ve alkol kullanma oranları kadınlardan anlamlı ölçüde yüksek bulunmuştur.

TEKHARF çalışmasında, ortalama 7,4 yıl izlemde hipertansiyonun hayat tarzı ve metabolik belirleyicileri incelenmiştir. Yaşları $46 \pm 12$ yıl olan 2427 kişide bu süre içerisinde hipertansiyon insidansı hiç sigara içmeyenlerde $7,23 / 1000$ hasta yılı iken, sigara içenlerde 7,78/1000 hasta yılı olarak belirtilmiştir (8). ABD'de yapılan bir çalışmada, alkol tüketiminin azaltılması hipertansiyon kontrolünde en önemli yaklaşım olarak belirtilmiştir (21).

$\mathrm{Bu}$ araştırmada, erkek hastaların $\% 47,5^{\prime} \mathrm{i}$, kadın hastaların \%36,0'ı düzenli fiziksel aktivitede bulunduğunu belirtmiş ve gruplar arasındaki fark anlamlı bulunmuştur. Sedanter yaşam süren kişilerde hipertansiyon gelişme riskinin, düzenli fiziksel aktivitesi olanlara göre \%20-50 daha fazla olduğu bildirilmektedir (22). Ankara'da yapılan bir araştırmada, erkek hastalarda egzersiz yapma oranının daha yüksek olduğu ve düzenli egzersiz yapan hastaların $(\% 9,4)$ kan basıncı kontrollerinin daha iyi olduğu belirlenmiştir (23). Düşük yoğunluklu ve düzenli fiziksel aktivitenin mortalitede yaklaşık \%20 azalma yaptığı gösterilmiştir (24). Bu nedenle hipertansif hastaların, haftada 5-7 gün en az 30 dakikalık orta düzeyde aerobik egzersiz (yürüme, hafif koşu, bisiklete binme veya yüzme) yapması önerilmektedir (24).

Hastaların BKI değerleri incelendiğinde, erkeklerin $\% 14,0$ 'ü kadınların \%32,5 'i obez; erkeklerin $\% 61,6$ 'sı kadınların ise \%32,3'ü fazla kilolu olarak saptanmıştır. Mersin'de yapılan bir çalışmada, hipertansiyon ile obezitenin birlikteliğinin fiziksel fonksiyon üzerinde negatif etkisi olduğu saptanmıştır (17). BKİ değeri artıkça hipertansiyon görülme sıklığının da önemli ölçüde arttığı bilinmektedir. Sivas'ta yapılan bir çalışmada, BKI değeri 20'nin altında olanlarda hipertansiyon görülme sıklığı \%3,9 iken, 40 ve üzerinde olanlarda $\% 45,2$ bulunmuştur (25).

Hipertansiyonlu bireylerin hastalıklarına yönelik bazı beslenme alışkanlıklarını doğru uygulama durumuna bakıldığında (haftada bir veya daha az) hızlı atıştırmalık besin tüketiminin erkeklerde daha fazla olduğu saptanmıştır. Bunun nedeni, erkeklerin ev dışında çalışma oranlarının fazla olmasına bağlı mesai saatleri içerisinde yemeğe ayrılan vaktin kısıtlı olması olabilir.

Araştırma grubunda fazla tuzlu, yağda kızartılmış ve hızlı atıştırmalık besin tüketme oranı yaş gruplarına göre incelendiğinde, 40 yaş altı hastaların bu yiyecekleri daha fazla tükettikleri görülmüştür. Eskişehir'de "fast-food" alanında faaliyet gösteren bir restoranda yapılan bir çalışmaya göre; gelenlerin \%7,0'si 12-18; \%62,0'si 18-26; \%19,0'u 26-35 ve \%12,0'si 35 yaş ve üzeri yaş grubundadır (26). 
Araştırmada hızlı atıştırmalık tüketme oranları üniversite mezunlarında en yüksek seviyededir. Son yıllarda özellikle büyük şehirlerdeki hızlı çalışma temposu, ulaşım zorluğu ve zaman kısıtlılığı gibi nedenlerle, yeme alışkanlıklarında değişiklikler görülmektedir. Mesai saatleri içerisindeki kısa yemek molaları tüketicilerin "fastfood" tarzı beslenmeye yönelmelerine neden olmaktadır. Bu araştırma sonucunda da üniversite mezunu olan kişilerin çalışma koşulları nedeniyle hızı ıtıştırmalık tüketimi artmış olabilir (27).

Araştırma grubundaki hastaların yağda kızartılmış ve hızı atıştırmalık besin tüketim oranı hipertansiyon nedeniyle takip sürelerine göre değerlendirildiğinde 11 yıl ve üzeri hipertansiyonu olanlarda bu oran en düşük seviyededir. Bu bulgulara dayanılarak kişilere tanı konduktan yıllar sonra bu besinleri daha az tükettikleri söylenebilir.

Araştırmaya katılan kişilerin hipertansiyon tanısı konulmadan önce \%18,3'ü tuzsuz veya az tuzlu yemek yediğini belirtirken, tanı konulduktan sonra bu oran \%70,5'e yükselmiştir. Bu verilere göre tanı aldıktan sonra hastaların tuz tüketimi konusunda daha dikkatli oldukları söylenebilir. Epidemiyolojik araştırmalar tuz alımının hipertansiyon kontrolünde etkili olduğunu göstermiştir. Ankara'da yapılan bir çalışmada, hipertansiyon hastalarında en fazla uygulanan yaşam tarzı değişikliği tuz kısıtlaması olarak belirlenmiştir (28). Sivas'ta yapılan bir araştırmada da hastaların \%67,8'inin hipertansiyon tanısı aldıktan sonra tuz kullanımını kısıtladıkları saptanmıştır (25).

Katılımcıların hipertansiyon tanısı aldıktan sonra zeytinyağı kullanımını artırdıkları; diğer yağların kullanımını ise azalttıkları belirlenmiştir. Hastaların tanı aldıktan sonra bu konuda daha bilinçli davrandıkları söylenebilir. İzmir'de yapılan bir araştırmada, hastaların \%78,6'sının hipertansiyon tanısı aldıktan sonra hayvansal yağ tüketimini azalttığı saptanmıştır (29). ABD'de yapılan bir çalışmada, ilaçla tedavi dışında en önemli yaklaşımlar arasında kilo verme, tuz kısıtlaması ve doymuş yağ kullanımının azaltıması olduğu bildirilmiştir (30). Araştırma sonuçlarımız da literatürle paralellik göstermektedir.

Hipertansiyon kontrolünde ilaç tedavisinin yanında, destekleyici tedavilerin de yeri büyüktür. Destekleyici yöntemler arasında yoga, akupunktur, aromaterapi, besin destekleri, bitkisel terapiler, solunum terapileri ve daha birçok yöntem bulunmaktadır. Araştırmaya katılan hastaların $\% 36,8^{\prime} \mathrm{i}$, kan basınçları yükseldiğinde hekime başvurduğunu, \%63,2'si limon suyu, sarımsak gibi besinleri aldıklarını belirtmiştir. Avrupa Kardiyoloji Derneği Kılavuzunda, hipertansiyonda özel bir endikasyon olmadığı durumlarda, başlangıçta ilaç tedavisi uygulanmaması gerektiği belirtilmiştir. Öncelikle diyet ve yaşam tarzı değişiklikleri yapılması (kilo verme, tuz alımının kısıtlanması, fiziksel egzersiz, sigaranın bırakılması, vb.) önerilmektedir (31). Efe ve arkadaşlarının (32) yaptığı çalışmada, hipertansiyonu olan bireylerin $\% 74,7$ 'sinin destekleyici tedavi kullandıkları, en çok bitkisel yöntemleri uyguladıkları, bitkisel tedavi yöntemlerinden de en fazla limonu tercih ettikleri saptanmıştır. Adıbelli ve arkadaşlarının (33) yaptığı çalışmada ise hipertansiyon hastalarının $\% 72,5$ 'inin kan basıncını kontrol altında tutmak için destekleyici tedavi kullandığı ve en fazla bitkisel tedavi yöntemlerinden faydalandıkları belirlenmiştir. Biçen ve arkadaşlarının (34) yaptıkları çalışmada, hipertansiyon hastalarında bitkisel ürün kulanım oranı \%53,0 olarak bildirilmiştir.

Hipertansiyon kontrolünde ilaç tedavisi yerine sadece destekleyici tedavi uygulanması veya yanlış uygulanan yöntemler uygun tedavinin sürdürülmesini engellemektir. Kişilerin kan basıncı yükseldiğinde destekleyici tedavileri fazla oranda tercih etmesi bu konuda toplumun daha fazla bilgilendirilmesi gerektiğini göstermektedir.

\section{Sonuç}

Sonuç olarak; önemli bir halk sağlığı sorunu olan hipertansiyonla mücadelede henüz istenilen hedeflere ulaşılamamıştır. Hastalık tanısı konduktan sonra hastaların beslenme ve diyetlerine dikkat etme yönündeki olumlu gelişmelere rağmen, hipertansiyon farkındalığı istenilen düzeyde değildir. Hastaların hipertansiyon kontrolü ve korunma önlemleri hakkındaki tutum ve davranışlarının yetersiz olduğu belirlenmiştir.

$\mathrm{Bu}$ sonuçlar ışığında; hipertansiyon hastalarının tedaviye uyumunu sağlamak için hastalık ve tedavisi konusunda düzenli eğitim programlarına katıımının sağlanması, düzenli doktor kontrolü ve ilaç kullanımı konusunda yönlendirilmesi, hipertansiyon hastalarına yönelik eğitimsel yayınların sayısının artırılması, sağlık personelinin düzenli hizmet içi eğitimi ve tedavi kurallarına titizlikle uyulması gerekmektedir.

Kan basıncını kontrol altına almak için hareketli yaşam, tuz ve doymuş yağlardan fakir diyetle beslenme, sigara ve alkol kullanmama önerilmelidir. Sofrada tuzluk bulundurmaktan 
kaçınılmalı ve ev dışında yenilen yemeklerin tuzsuz hazırlanması talep edilmelidir. Hastaların diyete uyumunu sağlamak için, diyetisyen ve diğer sağlık personeli ile iş birliği içinde, hastalığa özel diyet programları hazırlanmalıdır. Ayrıca hastaların düzenli egzersiz ve fiziksel aktivite durumlarını artırmak haftanın 5-7 günü, 30-60 dakika ortaşiddette dinamik egzersiz önerilmelidir.

\section{Araştırmanın Sınırlılıkları}

Çalışmanın aile sağlığı merkezlerine başvuran hastalar üzerinde yapılmış olması nedeniyle, elde edilen sonuçlar araştırma bölgesindeki tüm hipertansiyon hastalarına genellenemez. Ayrıca hastaların kan basıncı ölçümü yapılamadığı için hipertansiyon kontrol durumları değerlendirilememiştir.

\section{Kaynaklar}

1. Who.int (homepage on the Internet) Global Atlas on Cardiovascular Disease Prevention and Control 2011 (cited March 2017). Available from: www.who.int.

2. Who.int (homepage on the Internet) Global Status Report on Noncommunicable Diseases 2014 (cited March 2017). Available from: www.who.int.

3. Tuik.gov (İnternet ana sayfa) Türkiye İstatistik Kurumu, Ölüm Nedeni İstatistikleri 2015 (Güncelleme:24 Mart 2016, Erişim tarihi: Mart 2017). Erişim: www.tuik.gov.tr/PdfGetir.do?id=21526.

4. Onat A, Karakoyun S, Akbaş T, ve ark. TEKHARF 2014 taraması ve Türkiye'de coğrafi bölgelere göre ölüm oranı ile koroner hastalık insidansı. Turk Kardiyol Dern Ars 2015; 43 (4): 326-32.

5. Turkhipertansiyon.org (İnternet ana sayfa) Türk Hipertansiyon ve Böbrek Hastalıkları Derneği Prevalans çalışması PatenT2 (Erişim tarihi Mart 2017).Erişim: www.turkhipertansiyon.org/prevelanscalismasi.php.

6. Metsend.org (internet ana sayfa) Metabolik Sendrom Araştırma Grubu. METSAR sonuçları.(Erişim tarihi: Eylül 2018). Erişim: http://www.metsend.org/pdf/Metsar-metsend.pdf.

7. Erdine S. How well is hypertension controlled in Europe? J Hypertens 2000;18 (9): 1348-9.

8. Bilir N, Çöl M, Kumbasar D ve ark. Birinci Basamakta Kronik Hastalıklar Kontrol Programı /Hipertansiyon. Ankara: Onur Matbaacılık Ltd. Şti; 2003: 21-35.

9. Özkan S, Yılmaz E. Hastanede çalışan hemşirelerin sağlıklı yaşam biçimi davranışları. F Ü Sağ Bil Tıp Derg 2008; 3 (7): 90-105.

10. Arıcı M, Birdane A, Güler K ve ark. Türk hipertansiyon uzlaşı raporu. Turk Kardiyol Dern Ars 2015; 43 (4): $402-9$.

11. Öksüz E. Hipertansiyonda klinik değerlendirme ve ilaç dışı tedavi. STED 2004;13 (3):99-104.

12. Mancia G, Fagard R, Narkiewicz K,et al. The Task Force for the Management of Arterial Hypertension of the European Society of Hypertension (ESH) and of the European Society of Cardiology (ESC). Eur Heart J 2013; 34 (28): 2159-219.

13. Temd.org (İnternet anasayfa) Obezite Tanı ve Tedavi Klavuzu. (Erişim tarihi:Temmuz 2018) Erişim: www.temd.org.tr

14. He J, Muntner P, Chen J, et al. Factors Associated with hypertension control in the general population of the United States. Arch Intern Med 2002; 162 (9): 1051-8.

15. Aydemir Ö. Sağlıkta yaşam kalitesinin klinik uygulamalarda kullanımı. Sağlıkta Birikim 2006; 1: 9-13.

16. Wee HL, Cheung YB, Li SC, Fong KY, Thumboo J. The impact of diabetes mellitus and other chronic medical conditions on health-related quality of life: is the whole greater than the sum of its parts? HQLO 2005; 3 (1): 2.

17. Şaşmaz CT, Buğdaycı R, Tezcan H, Kurt A Ö. Mersin İlinde 65 yaş ve üzerinde hipertansiyon farkında olma, tedavi alma ve kontrol durumu: 14 Sağlık Ocağı Bölgesinde 1143 kişiyi kapsayan bir prevalans çalışması. Diyarbakır: 8. Ulusal Halk Sağlığı Kongre Kitabı;(Eylül 2002): 627-9.

18. Solmaz T. Evde Yaşayan 65 Yaş ve Üzeri Yaşlı Bireylerin İlaç Kullanımı ve Kendi Kendine İlaç Kullanım Yetisi. Konya: Selçuk Üniversitesi Sağlık Bilimleri Enstitüsü, Halk Sağlığı Hemşireliği Anabilim Dalı. Yüksek Lisans Tezi 2008: 58-64.

19. Arpacı F, Açıkel CH, Şimşek I. Ankara'da yaşayan bir grup yaşının ilaç kullanım tutumları. TAF Prev Med Bull 2008; 7 (6): 515-22. 
20. Akkuş $Y$, Karatay $G$. Kars'ta 60 yaş üstü bireylerin ilaç kullanım bilgi ve davranışlarının değerlendirilmesi. TÜBAV Bilim 2011; 4 (3): 214-20.

21. Okonofua EC, Cutler NE, Lackland DT, Egan BM. Ethnic differences in older Americans: Awareness, knowledge, and beliefs about hypertension. Am J Hypertens 2005;18(7):972-9.

22. Jennings GL. Exercise, blood pressure: Walk, run or swim? J Hypertens 1997; 15 (6): 567-9.

23. Aypak C, Önder Ö, Dicle M, Yıkılkan H, Tekin H, Görpelioğlu S. Hipertansiyon hastalarının tedaviye uyumları ve kan basıncı kontrollerinin değerlendirilmesi. Cukurova Med J 2013; 38 (2): 224-32.

24. Rossi A, Dikareva A, Bacon SL, Daskalopoulou SS. The impact of physical activity on mortality in patients with high blood pressure: a systematic review. J Hypertens 2012; 30 (7): 1277-88.

25. Özdemir L, Sümer H, Koçoğlu G, Polat H. Prevalence of hypertension and affecting factors among women at the age of 30 years and over living in the region of Sivas Emek Health House. Cumhuriyet Med J 2001; 23 (1): 9-14.

26. Filiz Z, Çemrek F. Tüketici Memnuniyeti Analizi ve Gıda (Fast-Food) Sektöründe Bir Uygulama. DEÜ SBE Dergisi 2008; 10 (1): 59-84.

27. Tayfun A, Tokmak C. Tüketicilerin Türk Usulü Fast Food İşletmelerini Tercih Etme Sebepleri Üzerine Bir Araştırma.Esosder2007;6(22),169-83. (Erişim tarihi: Eylül 2018). Erişim: http://dergipark.gov.tr/esosder/issue/6136/82301

28. Çöl M, Özdemir O, Ocaktan ME. Park Sağıı Ocağı bölgesindeki 35 yaş üstü hipertansiflerde tedavi-kontrol durumları ve davranışsal faktörler. AnkMedJ 2006; 59: 144-50.

29. Tokem $\mathrm{Y}$, Taşçı E, Yılmaz M. Hipertansiyon tanısı olan bireylerin evde hastalık yönetimlerinin incelenmesi. Turk J Card Nur 2013; 4 (5): 30-40.

30. Oliveria SA, Chen RS, McCarthy BD, et al. Hypertension knowledge, awareness, and attitudes in a hypertensive population. J Gen Intern Med 2005; 20: 219-25.

31. Kjeldsen SE. Guidelines Committee: 2003 European Society of Cardiology Guidelines for the management of arterial hypertension. J Hypertens 2003; 21 (6): 1011-53.

32. Efe D, Kılıç Akça N, Kiper S, Aydın G, Gümüş K. Hipertansiyonu olan bireylerin kan basıncını düşürmeye yönelik kullandıkları destekleyici yöntemler. Spatula DD 2012; 2 (4): 207-12.

33. Adibelli Z, Dilek M, Akpolat T. Lemon juice as an alternative therapy in hypertension in Turkey. Int J Cardiol 2009 Jun 26; 135 (2): 58-9.

34. Biçen C, Elver Ö, Erdem E ve ark. Hipertansiyon hastalarında bitkisel ürün kullanımı. J Exp Clin Med 2012; 29 (2): 109-12. 